\title{
Strategi meningkatkan Minat Menabung di Bank Syariah melalui Penerapan Religiusitas
}

\author{
Yulia Putri ${ }^{1}$, Ani Solihat ${ }^{2}$, Rani Rahmayani ${ }^{3}$, Iis Iskandar ${ }^{4}$, Andry Trijumansyah $^{5}$ \\ Universitas Bina Sarana Informatika $a^{1,2,3,4,5}$ \\ putriyulia49@gmail.com¹, aniaja2608@yahoo.com², rani.rrh@bsi.ac.id ${ }^{3}$, iis.iik@bsi.ac.id ${ }^{4}$ \\ andry.atj@bsi.ac.id ${ }^{5}$
}

\begin{abstract}
ABSTRAK
Penelitian ini bertujuan untuk menganalisis strategi meningkatkan minat menabung di Bank Syariah melalui penerapan religiusitas dan minat menabung di Bank Syariah. Inti masalah penelitian ini mengenai penerapan religiusitas masyarakat Indonesia untuk segala aspek terutama dalam mengelola keuangan sehingga mempengaruhi minat masyarakat dalam memilih Bank dan pertumbuhan Bank Syariah berbanding terbalik dengan pertumbuhan penduduk mayoritas muslim di Indonesia sehingga perlu dilakukan analisis mengenai penerapan religiusitas terhadap peningkatan minat menabung masyarakat. Teknik pengumpulan data dalam penelitian ini adalah observasi, wawancara, dokumentasi, dan penyebaran kuesioner. Penelitian ini menggunakan metode yaitu kuantitatif dengan pendekatan statistik deskriptif dan verifikatif. Analisis data menggunakan uji statistik yang terdiri dari analisis regresi sederhana, analisis korelasi dan koefisien determinasi, dan uji t. Teknik pengambilan sampel yang digunakan adalah sampling insidental dan jumlah sampelnya adalah 98 orang dari jumlah populasi nasabah Bank Syariah Mandiri KCP Antapani Bandung sebanyak 5.664 nasabah. Hasil penelitian menunjukan bahwa hubungan religiusitas termasuk dalam kategori rendah, tetapi mengarah positif. Pengujian yang dilakukan secara parsial variabel religiusitas berpengaruh signifikan terhadap minat menabung masyarakat di Lingkungan Bank Syariah Mandiri KCP Antapani Bandung.
\end{abstract}

Kata kunci : Religiusitas, Minat Menabung, Bank Syariah

\begin{abstract}
The study aims to analyze the strategy of increasing interest in saving in Syaria Banks through the application of religiosity. The core problem of this research concerning the application of Indonesian society's religiosity for all aspects, especially in managing finance, thus influencing the interest of the community in choosing the Bank and the growth of Islamic Banks is inversely proportional to the growth of the majority Muslim population in Indonesia so that an analysis of the application of religiosity is needed to increase the interest in savings. Data writing techniques in this study were observation, interviews, documentation, and questionnaires. This study uses a quantitative method with descriptive and verification statistical approaches. Data analysis uses statistical tests consisting of simple regression analysis, correlation analysis and coefficient of determination, and t test. The sampling technique used is incidental sampling and the number of samples is 98 people from the total cutomer population of Bank Syariah Mandiri KCP Antapani Bandung as many as 5,664 customers. The results showed that the relationship of religiosity was in the low category, but has positive direction. Partial testing of religiosity variables has a significant effect on the interest in saving society in the Bank Syariah Mandiri Environment KCP Antapani Bandung.
\end{abstract}

Keywords: Religiusity, Interest of Saving, Syariah Bank 


\section{PENDAHULUAN}

Sebuah artikel memaparkan rasio aset perbankan syariah masih jauh dibandingkan dengan aset perbankan konvensional. Perbandingan bank syariah dan bank konvensional juga berbanding terbalik jika dilihat dari jumlah penduduk muslim di Indonesia. Catatan Otoritas Jasa Keuangan (OJK) menunjukkan total aset bank umum pada akhir tahun 2017 sudah mencapai Rp. 7.387 triliun. Sementara total aset perbankan syariah baru sebesar Rp 424 triliun. Dari jumlah tersebut memaparkan pertumbuhan rasio aset bank syariah terhadap bank umum baru sebesar 5,73\%. Besaran rasio ini masih jauh dari rencana OJK yang menginginkan setidaknya mencapai 10\% (Hidayat, 2018).

Dari pemaparan di atas ditemukan bahwa pernyataan tersebut sesuai dengan Catatan Otoritas Jasa Keuangan (OJK) per Februari 2018 mengenai statistik perbankan syariah tentang perkembangan total aset dan jaringan kantor bank umum syariah masih rendah daripada perkembangan total aset dan jaringan kantor bank umum konvensional. Hal tersebut dapat dilihat dari segi pertumbuhan aset bank umum syariah per Februari 2018 yang baru mencapai 289,487 triliun, jumlah kantor bank syariah sebanyak 1.828 kantor, dan jumlah ATM bank syariah sebanyak 2.584 ATM yang tersebar di seluruh Indonesia (Statistik Perbankan Syariah OJK, 2018).

Minat dapat dikatakan suatu ketertarikan terhadap sesuatu dan kecenderungan memilih apa yang diinginkan. Salah satunya dengan ketertarikan dan kecenderungan terhadap minat menabung, misalnya kecenderungan seseorang yang religius cenderung memilih bank syariah dari pada bank konvensional karena berdasarkan syariat agama konsep riba dalam bank konvensional itu tidak dibenarkan dalam islam. Menurut Damayanti (2017:18) "seorang calon nasabah akan berminat pada bank syariah ketika ada produk atau sistem yang dirasakan menguntungkan dirinya".

Minat tidak bisa luput dari perilaku seseorang dalam aktivitas sehari-hari. Kotler dalam Nisak, Saryadi, \& Suryoko (2013:2) menyebutkan perilaku seseorang biasanya dipengaruhi oleh beberapa faktor seperti kebiasaan dalam keluarga, keyakinan, budaya, gaya hidup, dan hal-hal lain yang berhubungan dengan lingkungan hidup. Hal ini menjelaskan bahwa kaitan perilaku seseorang berkaitan erat dengan pemilihan minat terhadap sesuatu. Perilaku seseorang juga berkaitan dengan pengambilan keputusan sesuai dengan kebutuhan dan pertimbangan orang tersebut (Roisah \& Riana, 2016:103).

Astogini memaparkan dalam Sari \& Anwar (2018:26) bahwa perilaku konsumen Indonesia berkaitan dengan religiusitas dilihat dari cara pengambilan keputusan pembelian produk. Perilaku konsumen Indonesia yang religius terlihat dari masyarakat Indonesia sangat peduli terhadap sesuatu yang diperbolehkan atau tidak diperbolehkan dalam agama, misalnya seorang muslim tidak akan membeli produk tanpa label halal yang dikeluarkan oleh MUI karena MUI sebagai suatu lembaga yang menjamin kehalalan suatu produk. Hal itu pun berlaku untuk pemilihan bank dalam menabung.

Religiusitas cenderung menaati suatu keyakinan, memiliki nilai hukum, dan menjalani suatu ketaatan yang berhubungan dengan keyakinan seseorang. Rohmatun \& Dewi (2017:28) memaparkan bahwa agama sebagai pedoman hidup manusia. Tingkat religiusitas seseorang dapat menentukan perilaku seseorang dalam kehidupan sehari-hari.

ISSN: 1829-8680 E-ISSN: 2599-0039 
Rohaeni, Hikmah, \& Rahmayani (2018:147) memaparkan sama seperti cara seseorang dalam berpakaian yang sopan dan sesuai dengan norma-norma agama. Religiusitas nasabah dapat berkembang menjadi minat apabila penerapan sikap religius dalam segala aspek, misalnya dalam pengelolaan keuangan.

Dalam penelitian Sari \& Anwar (2018:32) memaparkan bahwa tingkat religiusitas berpengaruh secara positif dan signifikan terhadap minat menabung di perbankan syariah ditunjukkan dengan besarnya nilai siginifikansi sebesar 0,000 yang lebih kecil dari nilai alpha 5\% atau 0,05 dengan nilai $t$ test menunjukkan angka 24,5\%. Hal ini mengindikasikan semakin tinggi tingkat religiusitas nasabah maka semakin tinggi minat menabung di perbankan syariah.

Produk perbankan syariah juga mempengaruhi minat menabung di bank syariah jika produk itu bermanfaat bagi nasabah. Solihat, Hakim, \& Setiawati (2016:244) memaparkan bahwa produk sebagai salah satu elemen yang sangat penting dalam pemasaran. Wijayani (2017:3) memaparkan bahwa dalam Al-Qur'an surah Al-Baqarah ayat 275, 278-179, Ali-Imran ayat 130, dan An-Nisa' ayat 29 sistem perbankan syariah dijalankan atas dasar filosofi religiusitas, landasan keadilan, dan orientasi falah. Hal ini menunjukkan bahwa bank syariah perlu membuat sebuah strategi yang mengeluarkan produk di dalam agama itu diperbolehkan.

Roisah \& Iskandar (2013:24) memaparkan bahwa dalam sebuah perusahaan peranan strategi pemasaran sangat penting untuk menghadapi lingkungan yang dinamis, sehingga memperoleh keunggulan tertentu. Penggunaan strategi oleh bank syariah untuk menarik minat nasabah salah satunya dengan mengeluarkan produk berbasis syariah. Produk syariah tersebut misalnya, Titipan atau Simpanan (Al-Wadiah dan Mudharabah), Bagi Hasil (Al-Mudharabah, Al-Musyarakah, Al-Muzaraah, dan Al-Musaqah), Jual Beli (Bai' Al-Murabahah, Bai' As-Salam, Bai' Al-Istishna, dan Al-Ijarah Al Muntahia BitTamlik), dan jasa (Al-Wakalah, Al-Kafalah, Al-Hawalah, Ar-Rahn, dan Al-Qardh).

Produk yang berdasarkan syariat islam tentu dapat menarik minat nasabah untuk masuk atau berkontribusi dalam bank syariah terlebih pada masyarakat Indonesia yang mayoritasnya muslim. Salah satu bank syariah yang menerapkan produk bagi hasil salah satunya Bank Syariah Mandiri. Bank Syariah Mandiri (BSM) sebagai salah satu perbankan yang menggunakan sistem operasional berdasarkan kaidah syariah. Sistem Syariah yang dijalankan oleh BSM sesuai dengan syariat Islam yang telah mendapat izin operasional dari Dewan Syariah Nasional (DSN) dan dalam pelaksanannya mendapat pengawasan dari Dewan Pengawas Syariah (DPS).

Bagi hasil salah satu sistem syariah yang digunakan dalam Perbankan Syariah. Bagi hasil merupakan prinsip kerja sama usaha dalam bentuk investasi serta menawarkan tingkat return yang dapat ditentukan sesuai perjanjian. Prinsip bagi hasil di dalam bank syariah terdapat dalam akad mudharabah. Pada konstruksi prinsip mudharabah bank syariah memposisikan diri sebagai mitra kerja antara si penabung dan pengusaha untuk mendapatkan keuntungan (Damayanti, 2017:18).

Berdasarkan latar belakang di atas penulis tertarik untuk melakukan penelitian mengenai penerapan religiusitas dalam strategi peningkatan minat menabung sehingga 
penulis mengambil judul penelitian mengenai "Strategi Meningkatkan Minat Menabung di Bank Syariah Melalui Penerapan Religiusitas".

\section{LANDASAN TEORI}

\section{Religiusitas}

Menurut Farid \& Aviyah (2014:127) religiusitas adalah "internalisasi nilai-nilai agama yang ada dalam diri seseorang, internalisasi di sini berkaitan dengan kepercayaan terhadap ajaran-ajaran agama baik di dalam hati maupun dalam ucapan, kepercayaan ini kemudian diaktualisasikan dalam perbuatan dan tingkah laku sehari-hari”.

Menurut Rohmatun \& Dewi (2017:29) Komitmen terhadap agama yang tercermin dalam sikap dan perilaku seseorang akan meningkatkan keputusan pembelian berdasarkan pemahaman religiusnya.

Menurut Karim (2016) pengguna jasa keuangan di Indonesia terbagi ke dalam tiga bagian yakni conventional loyalist, sharia loyalist, dan financial mass. Persentase tertinggi profil penguna jasa keuangan berasal dari financial mass. Artinya mayoritas pengguna jasa keuangan di Indonesia memiliki dua akun, yakni akun pada lembaga keuangan konvensional dan akun pada lembaga keuangan syariah.

Menurut (Souiden \& Rani, 2015:5) religiusitas dan pengetahuan konsumen atas kehalalan suatu produk akan mempengaruhi perilakunya dalam mengambil keputusan pembelian.

Menurut Triana, Nurhasanah, \& Senjiati (2016:533) religiusitas pada Mahasiswa Fakultas Syariah Unisba berpengaruh secara simultan maupun parsial bersama dengan pendapatan sisa terhadap keputusan menabung.

Berdasarkan beberapa pengertian religiusitas oleh para ahli di atas maka penulis simpulkan bahwa religiusitas adalah sistem keyakinan atau aturan-aturan yang harus dilaksanakan, yang berhubungan dengan pendekatan diri dengan yang sakral untuk menumbuhkan pemahaman tentang hubungan dan tanggung jawab seseorang terhadap sekelompok orang dan tuhannya, maka terlihatlah sejauh mana seseorang berkomitmen pada agamanya kemudian diaktualisasikan dalam perbuatan dan tingkah laku sehari-hari.

\section{Dimensi Religiusitas}

Glock dan Stark dalam Farid \& Aviyah (2014:127) mengemukakan bahwa religiusitas memiliki lima dimensi, diantaranya (1) Dimensi Idiologis, (2) Dimensi Ritualistis atau Praktek, (3) Dimensi Intelektual atau Pengetahuan, (4) Dimensi Konsekuensi atau Pengamalan, (5) Dimensi Eksperensial atau Pengalaman 


\section{Perilaku Konsumen}

Perilaku konsumen seperti yang dikutip oleh Sumarwan dalam Nisak, Saryadi, \& Suryoko (2013:45) adalah "Perilaku yang ditujukan oleh orang-orang dalam merencanakan, membeli, dan menggunakan barang-barang ekonomi dan jasa".

Schiffman dan Kanuk dalam Alamsyah (2016:148) mengemukakan bahwa "perilaku konsumen dapat diartikan sebagai sikap konsumen dalam mencari, membeli, menggunakan, mengevaluasi, dan mengkonsumsi produk atau jasa yang mereka harapkan dapat memuaskan kebutuhan mereka".

Berdasarkan penjelasan di atas maka penulis simpulkan bahwa perilaku konsumen adalah perilaku yang ditunjukan seorang individu atau rumah tangga dalam merencanakan, membeli, menggunakan, mengevaluasi, dan mengonsumsi suatu produk atau jasa yang dapat memuaskan konsumen dan memerlukan kegiatan-kegiatan secara langsung untuk memenuhi kebutuhan tersebut.

\section{Minat Menabung}

Cahyani (2013:4) menyatakan bahwa "minat (interest) digambarkan sebagai situasi seseorang sebelum melakukan tindakan, yang dapat dijadikan dasar untuk memprediksi perilaku atau tindakan tersebut".

Minat menabung oleh Kotler dalam Cahyani (2013:4) diasumsikan sebagai "perilaku yang muncul sebagai respon terhadap objek yang menunjukkan keinginan nasabah untuk melakukan pencarian informasi”.

Menurut Howard dan Sheth dalam Priansa (2017:164) minat menabung merupakan sesuatu yang berhubungan dengan rencana nasabah untuk memilih produk tertentu. Minat menabung juga dapat dikatakan sebagai pernyataan mental dari nasabah untuk pemilihan produk tabungan tertentu.

Assael dalam Priansa (2017:164) menyatakan bahwa minat menabung merupakan kecenderungan nasabah untuk memilih suatu produk atau mengambil tindakan yang berhubungan dengan pemilihan untuk tingkat kemungkinan nasabah melakukan penyimpanan.

Djamarah dalam Damayanti (2017:19) menyatakan bahwa minat adalah kecenderungan yang menetap untuk memperhatikan dan mengenang beberapa aktivitas. Seseorang yang berminat terhadap suatu aktivitas akan memperhatikan aktivitas itu secara konsisten dengan rasa senang.

Berdasarkan penjelasan dari beberapa ahli di atas maka penulis simpulkan bahwa minat menabung adalah situasi seseorang sebelum melakukan tindakan sebagai respon terhadap keinginan nasabah untuk melakukan pencarian informasi pada produk tertentu atau kecenderungan nasabah untuk memilih suatu produk tabungan yang nasabah rasa cocok sehingga seseorang yang memiliki minat akan memperhatikan produk itu. 


\section{Dimensi Minat}

Minat menabung dapat terlihat dengan berbagai pengukuran dimensi, Priansa (2017:168) menyebutkan bahwa secara umum dimensi tersebut berkenaan dengan empat dimensi pokok yaitu (1) Minat Transaksional, (2) Minat Referensial, (3) Minat Preferensial, (4) Minat Eksploratif

Berdasarkan penjelasan dimensi di atas terdapat beberapa indikator yang lebih spesifik untuk minat menabung. Menurut Schiffman \& Kanuk dalam Sari (2017:185) indikator-indikator dari minat menabung tersebut antara lain: (1) Tertarik untuk mencari informasi mengenai produk, (2) Mempertimbangkan untuk membeli, (3) Tertarik untuk mencoba, (4) Ingin mengetahui produk, (5) Ingin memiliki produk.

\section{Kerangka Pemikiran}

\section{Gambar 1 \\ Kerangka Pemikiran}

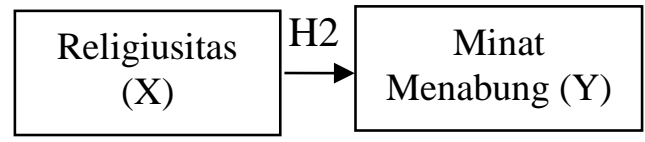

Sumber: Data diolah penulis, 2018

\section{Hipotesis}

Menurut Sugiyono (2016:99) hipotesis merupakan jawaban sementara terhadap rumusan masalah penelitian, selanjutnya rumusan masalah penelitian dinyatakan dalam bentuk kalimat pertanyaan. Dikatakan sementara karena jawaban yang diberikan baru didasarkan pada teori yang relevan, belum didasarkan pada fakta - fakta empiris yang diperoleh melalui pengumpulan data. Berdasarkan rumusan masalah, maka penulis merumuskan hipotesis sebagai berikut: $\mathrm{H} 1=$ Religiusitas berpengaruh positif dan signifikan terhadap minat menabung

\section{PEMBAHASAN}

Responden dalam penelitian ini adalah masyarakat di lingkungan Bank Syariah Mandiri KCP Antapani Bandung. Penelitian ini terdiri dari dua variabel, religiusitas (X) dan minat menabung (Y). Variabel religiusitas diwakilkan oleh 16 pernyataan dan variabel minat menabung diwakilkan oleh 5 pernyataan.

\section{Uji Validitas}

Untuk menguji validitas setiap butir pernyataan, skor tiap pernyataan penulis korelasikan dengan skor total. Indeks validitas diperoleh pada setiap butir pernyataan dengan syarat minimum $r=0,165$. sehingga korelasi antara butir pernyataan dan skor yang kurang dari 0,165 dinyatakan tidak valid. 
Tabel 1

Nilai Uji Validitas

\begin{tabular}{clccl}
\hline Item & Pernyataan & $\begin{array}{c}\text { Nilai } \\
\text { Korelasi }\end{array}$ & $\begin{array}{c}\text { Nilai } \\
\text { Batas }\end{array}$ & Validitas \\
\hline 1 & R1 & 0,632 & 0,165 & Valid \\
\hline 2 & R2 & 0,584 & 0,165 & Valid \\
\hline 3 & R3 & 0,758 & 0,165 & Valid \\
\hline 4 & R4 & 0,708 & 0,165 & Valid \\
\hline 5 & R5 & 0,728 & 0,165 & Valid \\
\hline 6 & R6 & 0,734 & 0,165 & Valid \\
\hline 7 & R7 & 0,511 & 0,165 & Valid \\
\hline 8 & R8 & 0,685 & 0,165 & Valid \\
\hline 9 & R9 & 0,488 & 0,165 & Valid \\
\hline 10 & R10 & 0,531 & 0,165 & Valid \\
\hline 11 & R11 & 0,533 & 0,165 & Valid \\
\hline 12 & R12 & 0,458 & 0,165 & Valid \\
\hline 13 & R13 & 0,628 & 0,165 & Valid \\
\hline 14 & R14 & 0,417 & 0,165 & Valid \\
\hline 15 & R15 & 0,407 & 0,165 & Valid \\
\hline 16 & R16 & 0,517 & 0,165 & Valid \\
\hline 17 & MM1 & 0,436 & 0,165 & Valid \\
\hline 18 & MM2 & 0,415 & 0,165 & Valid \\
\hline 19 & MM3 & 0,607 & 0,165 & Valid \\
\hline 20 & MM4 & 0,420 & 0,165 & Valid \\
\hline 21 & MM5 & 0,597 & 0,165 & Valid \\
\hline & Sumber : Hasil Olah data SPSS, 2018
\end{tabular}

Keterangan

$\mathrm{R} 1=$ Religiusitas dan $\mathrm{MM}=$ Minat Menabung

Tabel 1 menjelaskan bahwa setelah melakukan uji validitas, nilai korelasi semua item pernyataan religiusitas dan minat menabung $>0,165$. Dengan demikian semua item masing-masing variabel memenuhi syarat dalam pengujian validitas dan dinyatakan valid.

\section{Uji Reliabilitas}

Abhimantra, Maulina, \& Agustianingsih (2013:173) memaparkan bahwa uji reliabilitas penulis lakukan untuk mengetahui kehandalan dari kuesioner yang penulis sebar dalam mengukur suatu variabel. Penelitian reliabilitas penulis lakukan dengan menggunakan cronbach alpha. Koefisien cronbach alpha > 0,60 menunjukan bahwa data yang terkumpul reliabel.

Tabel 2

Uji Reliabilitas

\begin{tabular}{ccc}
\hline Variabel & $\begin{array}{c}\text { Cronbach's } \\
\text { Alpha }\end{array}$ & Keputusan \\
\hline Religiusitas & 0,891 & Reliabel \\
\hline $\begin{array}{c}\text { Minat } \\
\text { Menabung }\end{array}$ & 0,814 & Reliabel \\
\hline \multicolumn{2}{c}{ Sumber : Hasil olah data SPSS, 2018 }
\end{tabular}

ISSN: 1829-8680 E-ISSN: 2599-0039

https://doi.org/10.29313/performa.v16i1.4532 
Berdasarkan tabel 2 nilai cronbach's alpha dari untuk variabel religiusitas dan minat menabung nilainya lebih besar dari 0,60 . Sehingga masing-masing variabel tersebut reliabel dan layak untuk di uji.

\section{Uji Korelasi dan Koefisien Determinasi}

Tabel 3

Model Summary ${ }^{b}$

\begin{tabular}{lcccc}
\hline \multicolumn{5}{c}{ Model Summary } \\
Model & $\mathrm{R}$ & R Square & $\begin{array}{c}\text { Adjusted R } \\
\text { Square }\end{array}$ & $\begin{array}{c}\text { Std. Error of the } \\
\text { Estimate }\end{array}$ \\
\hline 1 &, $392^{\mathrm{a}}$ &, 154 &, 145 & 2,96045 \\
\hline a. Predictors: (Constant), Religiusitas & & \\
\hline b. Dependent Variable: Minat Menabung &
\end{tabular}

Sumber : Hasil olah data SPSS, 2018

Pada Tabel 3 nilai $\mathrm{R}$ menunjukan seberapa kuat hubungan variabel religiusitas (X) terhadap minat menabung (Y), dalam hal ini religiusitas terhadap minat menabung memperoleh hubungan $(\mathrm{R})$ sebesar 0,392 yang berarti hubungan kedua variabel tersebut rendah.

Untuk nilai $R$ Square menunjukan seberapa besar pengaruh variabel religiusitas $(\mathrm{X})$ terhadap minat menabung $(\mathrm{Y})$, dalam hal ini religiusitas terhadap minat menabung memiliki pengaruh sebesar 0,154 atau $15,4 \%$. Artinya pengaruh religiusitas terhadap minat menabung sebesar $15,4 \%$ dan sisanya $84,6 \%$ adalah variabel lain yang mempengaruhi, tetapi penulis tidak mempelajari lebih lanjut dalam penelitian ini.

\section{Uji Hipotesis}

Tabel 4

Koefisien

\begin{tabular}{|c|c|c|c|c|c|}
\hline & & Koefisien & & & \\
\hline & Model & Tidak & $\mathrm{T}$ & T & Sig. \\
\hline & & B & & & \\
\hline 1 & $\begin{array}{l}\text { (Nilai } \\
\text { Tetap) }\end{array}$ & 7,023 & 2,657 & 1,661 & (009, \\
\hline & Religiusitas & , 164 & 4,173 & 1,661 & ,000 \\
\hline & a. Vari & el Terikat: & Minat $\mathrm{N}$ & Ienabu & \\
\hline
\end{tabular}

Berdasarkan tabel 4 nilai koefisien regresi variabel minat menabung (Y) sebesar 7,023, $t_{\text {hitung }} 2,657, t_{\text {tabel }}$ dengan $\alpha=0,101,661$, dan probabilitas (sig) 0,009. Perolehan hasil uji $\mathrm{T}$, variabel $\mathrm{X}$ terhadap variabel $\mathrm{Y}$ adalah Ha: Terdapat pengaruh yang signifikan antara religiusitas terhadap minat menabung masyarakat secara parsial dan Ho:Tidak terdapat pengaruh yang signifikan antara religiusitas terhadap minat menabung masyarakat secara parsial.

Diketahui bahwa nilai t hitung variabel religiusitas terhadap minat menabung sebesar 4,173 > 1,661. Artinya Ha diterima dan Ho ditolak sehingga dapat disimpulkan 
bahwa terdapat pengaruh yang signifikan antara variabel religiusitas terhadap minat menabung.

\section{Pengaruh Religiusitas Terhadap Minat Menabung}

Hasil penelitian menunjukkan bahwa terdapat pengaruh yang signifikan antara religiusitas terhadap minat menabung dengan besar hubungannya sebesar 0,392. Untuk mengetahui pengaruh religiusitas terhadap minat menabung penulis melakukan perhitungan dengan cara mengkuadratkan nilai hubungan kemudian di kalikan dengan $100 \%$ sehingga memperoleh nilai sebesar $15,4 \%$.

Dapat diketahui bahwa nilai $\mathrm{t}$ hitung variabel religiusitas terhadap minat menabung adalah 4,173 > 1,661. Artinya terdapat pengaruh yang signifikan antara variabel religiusitas terhadap minat menabung. Berdasarkan analisa yang telah penulis lakukan dalam penelitian ini, bahwa religiusitas memiliki pengaruh yang positif terhadap minat menabung. Hal ini menunjukan bahwa religiusitas masyarakat memiliki pengaruh dalam minat menabung pada Bank Syariah Mandiri KCP Antapani Bandung.

Religiusitas dalam penelitian ini merupakan sejauh mana tingkat kereligiusan seseorang dalam mengelola keuangannya di perbankan syariah yang sesuai dengan syariat islam. Semakin tinggi tingkat kereligiusitasan seseorang maka semakin tinggi pula minat menabung seseorang pada Bank yang sesuai dengan syariat islam. Salah satunya yaitu di Bank Syariah Mandiri KCP Antapani Bandung sesuai dengan objek yang penulis jadikan penelitian.

Sesuai dengan pernyataan Hasan dalam Mu'in (2016:28) bahwa perilaku ekonomi sangat ditentukan oleh tingkat keimanan seseorang atau masyarakat. Perilaku ini kemudian membentuk kecenderungan perilaku konsumsi dan produksi sehingga perspektif tersebut berpengaruh terhadap minat menabung.

\section{KESIMPULAN DAN SARAN}

\section{Kesimpulan}

Berdasarkan hasil penelitian dan pembahasan yang telah penulis lakukan mengenai strategi meningkatkan minat menabung melalui penerapan religiusitas pada Bank Syariah Mandiri KCP Antapani Bandung maka penulis menarik kesimpulan (1) Berdasarkan temuan penelitian menunjukan bahwa Religiusitas masyarakat di lingkungan Bank Syariah Mandiri KCP Antapani Bandung sudah dalam kategori sangat baik. (2) Berdasarkan temuan penelitian menunjukan bahwa Minat menabung masyarakat di Lingkungan Bank Syariah Mandiri KCP Antapani Bandung sudah dalam kategori baik.

Berdasarkan temuan penelitian dari analisis korelasi menunjukkan bahwa penerapan religiusitas terhadap minat menabung memiliki hubungan yang rendah, tetapi berarah positif. Namun, hasil analisis secara parsial variabel religiusitas berpengaruh dan signifikan terhadap minat menabung. 


\section{Saran}

Berdasarkan dari kesimpulan di atas penulis bermaksud untuk memberikan saran (1) Bank Syariah Mandiri KCP Antapani Bandung perlu mempertahankan sifat religiusitas masyarakat di lingkungan Bank Syariah KCP Antapani Bandung. Berdasarkan hasil penelitian menunjukan religiusitas berpengaruh signifikan terhadap minat menabung. Namun, perlu adanya suatu sistem yang menekankan religiusitas agar masyarakat berminat pada Bank Syariah karena di Indonesia mayoritas penduduknya adalah muslim sehingga pertumbuhan bank syariah di Indonesiapun seimbang dengan pertumbuhan penduduk mayoritas muslim. Variabel religiusitas valid, reliabel, memiliki pengaruh, dan signifikan dalam penelitian ini, sehingga peneliti selanjutnya dapat menggunakan variabel ini untuk penelitian selanjutnya.

(2) Minat menabung masyarakat pada Bank Syariah Mandiri KCP Antapani sudah baik. Hal ini terlihat dari tanggapan masyarakat terhadap kuesioner yang baik. Namun, Bank Syariah Mandiri perlu mempertahankan dan memperhatikan hal-hal yang dapat menarik minat masyarakat tetap menabung di Bank Syariah Mandiri KCP Antapani Bandung seperti pemberian hadiah atau undian pada nasabah yang loyal. Variabel minat menabung valid, reliabel, memiliki pengaruh, dan signifikan dalam penelitian ini, sehingga peneliti selanjutnya dapat menggunakan variabel ini untuk penelitian selanjutnya.

(3) Berdasarkan hasil analisis penelitian variabel religiusitas memiliki pengaruh terhadap minat menabung dan signifikan. Hal ini perlu Bank Syariah sadari bahwa religiusitas berperan dalam strategi menarik minat menabung masyarakat. Namun, pengaruh religiusitas tersebut masih tergolong rendah sehingga perlu menambahkan variabel lain yang dapat menarik minat nasabah seperti promosi produk, hubungan masyarakat, dan pemasaran langsung.

Berdasarkan hasil analisis penelitian variabel religiusitas memiliki pengaruh dan signifikan terhadap minat menabung. Namun, hubungan dan pengaruhnya masih tergolong rendah sehingga perlu adanya penambahan variabel lain yang membuat pengaruh tersebut menjadi sangat kuat. Variabel yang dapat peneliti selanjutnya tambahkan seperti: promosi produk, hubungan masyarakat, pemasaran langsung, dan menjalin hubungan dengan lembaga-lembaga yang berbaur religiusitas. 


\section{DAFTAR PUSTAKA}

Abhimantra, A., Rahmi Maulina, A., \& Agustianingsih, E. (2013). Analisis Faktor-Faktor Yang Mempengaruhi Nasabah (Mahasiswa) Dalam Memilih Menabung Pada Bank Syariah. Proceeding PESAT (Psikologi, Ekonomi, Sastra, Arsitektur \& Tekniki Sipil), 5(10), 5-12. https://doi.org/10.13140/RG.2.2.30630.32324

Alamsyah, D. P. (2016). Kepercayaan Konsumen Pada Produk Organik. Jurnal Ecodemica, IV(2), 146-155.

Cahyani, A. F. (2013). Pengaruh Persepsi Bunga Bank dan Kualitas Pelayanan Terhadap Minat Menabung Pada Bank BNI Syariah di Kota Bandung. Journal of Social and Politic, 2(3), 1-9.

Damayanti, S. (2017). Pengaruh Pandangan Islam, Pelayanan dan Keamanan Terhadap Minat Nasabah untuk Menabung di Bank Syariah Mandiri Cabang x. Jurnal Manajemen Dan Pemasaran Jasa, 9(1), 17-34. https://doi.org/http://dx.doi.org/10.25105/jmpj.v9i1.1412

Farid, M., \& Aviyah, E. (2014). Religiusitas , Kontrol Diri Dan Kenakalan Remaja. Jurnal Psikologi Indoonesia, 3(02), 126-129. https://doi.org/https://doi.org/10.30996/persona.v3i02.376

Hidayat, S. (2018). Rasio aset bank syariah terhadap bank umum masih jauh dari 10. Retrieved from https://keuangan.kontan.co.id/news/rasio-aset-bank-syariahterhadap-bank-umum-masih-jauh-dari-10

Karim, A. A., \& Affif, A. Z. (2005). Islamic banking consumer behaviour in Indonesia: a qualitative approach. International Journal Islamic Finance, 5(1), 1-18.

Mu'in, A. (2016). Syudi Analisis Religiusitas Mahasiswa FE UNY yang Menabung di Bank Syariah. https://doi.org/10.1017/CBO9781107415324.004

Nisak, A., Saryadi, \& Suryoko, S. (2013). Pengaruh Kelompok Acuan dan Pengetahuan Tentang Perbankan Syari'ah Terhadap Minat Menabung di Perbankan Syari'ah Semarang. Jurnal Ilmu Administrasi Bisnis, 2(1), 44-50. Retrieved from https://ejournal3.undip.ac.id/index.php/jiab/article/download/1619/1613

Nurma Sari, F., \& Khoirul Anwar, M. (2018). Pengaruh Tingkat Religiusitas Santri Pondok Pesantren Darussalam Kediri Terhadap Minat Menabung Di Perbankan Syariah. Jurnal Ekonomi Islam, 1(1), 25-35. Retrieved from https://jurnalmahasiswa.unesa.ac.id/index.php/jei/article/view/23022

Priansa, D. J. (2017). Perilaku Konsumen dalam Persaingan Bisnis Kontemporer. (M. A. Firsada, Ed.) (1st ed.). Bandung: ALFABETA, CV.

Rohaeni, H., Hikmah, A. S., \& Rahmayani, R. (2018). Be Good Atitude Dalam Berpenampilan Pada UMKM “ Mang Piat" Kabupaten Bandung Barat. Jurnal

ISSN: 1829-8680 E-ISSN: 2599-0039 
Pengabdian Kepada Masyarakat, 1(1), 142-148.

Rohmatun, K. I., \& Dewi, C. K. (2017). Pengaruh Pengetahuan Dan Religiusitas Terhadap Niat Beli Pada Kosmetik Halal Melalui Sikap. Journal Ecodemica, 1(1), $27-35$.

Roisah, R., \& Iskandar, I. (2013). Pengaruh strategi pemasaran terhadap kepuasan nasabah pada pt bank tabungan negara kcp kopo. Jurnal Ecodemica, 1(2), 23-32. Retrieved from http://ejournal.bsi.ac.id/ejurnal/index.php/ecodemica/article/view/134

Roisah, R., \& Riana, D. (2016). Telaah hubungan citra merek, kualitas produk dan keputusan pembelian konsumen. Jurnal Ecodemica, IV(1), 100-107.

Rusdianto, H., \& Ibrahim, C. (2016). Pengaruh Produk Bank Syariah Terhadap Minat Menabung Dengan Persepsi Masyarakat Sebagai Variabel Moderating Di Pati. EQUILIBRIUM Jurnal Ekonomi Syariah, 4(1), 43-61. https://doi.org/10.21043/equilibrium.v4i1.1837

Sari, D. I. (2017). Strategi Promosi dan Store Interior Pada Industri Ritel. Jurnal Ecodemica, 1(2), 183-192.

Solihat, A., Hakim, L., \& Setiawati, S. D. (2016). Strategi produk cilok sebagai makanan khas kota bandung. Jurnal Ecodemica, IV(2), 242-249.

Souiden, N., \& Rani, M. (2015). Consumer attitudes and purchase intention towards islamic bank: The influence of religiosity. International Journal of Bank Marketing, 33(2), 143-161. https://doi.org/10.1108/IJBM-10-2013-0115

Triana, N., Nurhasanah, N., \& Senjiati, I. H. (2016). Pengaruh Tingkat Religiusitas dan Disposible Income Mahasiswa Fakultas Syari ' ah Unisba terhadap Minat Menabung di Bank BRI Syari ' ah Kantor Kas Unisba Influence The Level of Religiosity and Disposable Income Students of The Faculty of pendapatan dispos. Prosiding Keuangan Dan Perbankan Syariah, 2(2), 529-534. Retrieved from http://karyailmiah.unisba.ac.id/

Wijayani, D. R. (2017). Kepercayaan Masyarakat Menabung pada Bank Umum Syariah. Muqtasid, Jurnal Ekonomi Dan Perbankan Syariah, 8(1), 1-17. https://doi.org/http://dx.doi.org/10.18326/muqtasid.v8i1.1-17 